\section{DIARY}

APRIL

BDA Seminar - Growing your practice in challenging times

Date: 23 April 2010

Venue: Leeds Marriott Hotel, Leeds

HC2010 health informatics conference and exhibition

Date: 27-29 April 2010

Venue: International Conference

Centre (ICC), Birmingham

www.hc2010.co.uk

\section{MAY}

Dental Sedation Teachers

Group Annual Symposium 2010

Date: 14-15 May 2010

Venue: Dublin Dental School \& Hospital,

Trinity College Dublin, Ireland

Email:mary.clarke@dental.tcd.ie

www.dstg.co.uk

British Dental Conference

and Exhibition 2010

Date: 20-22 May 2010

Venue: Arena and Convention

Centre, Liverpool

Tel: 08701666625

Email:bda@delegate.com

www.bda.org

\section{JUNE}

Annual Meeting of the European Society of Dental Ergonomics

Date: 4-5 June 2010

Venue: Ghent University Hospital,

Ghent, Belgium

Email: secretary-general @esde.org www.esde.org

Training essentials - Managing stress in yourself and your team

Date: 17 June 2010

Venue: London

www.bda.org

Welsh Rural Postgraduate Unit, Institute of Rural Health,

11th Annual Rural Dental Conference

Date: 25 June 2010

Venue: Gregynog Hall, Newtown, Mid Wales Tel: 01686650800

BDA Seminar - Introduction to being an associate

Date: 25 June 2010

Venue: London

www.bda.org

\title{
RESEARCH AWARDS WINNER ANNOUNCED
}

Lisa Durning of the University of Manchester's School of Dentistry recently won the 2010 BDA/Dentsply Student Clinician Programme competition, the 33rd year the event has taken place.

She wins an all expenses paid trip to the Annual Session of the American Dental Association in Orlando, Florida in October. As part of the trip she will be invited to present the winning project, which was titled 'Analysis of a novel embryonic stem cell line exhibiting de novo promoter methylation of the metastasis suppressor E-cadherin'.

Ms Durning's victory is the culmination of nationwide competition which sees the winners of competitions at each of the UK and Irish dental schools pitched against each other in a national final to determine an overall winner. All entries must be previously unpublished or presented.

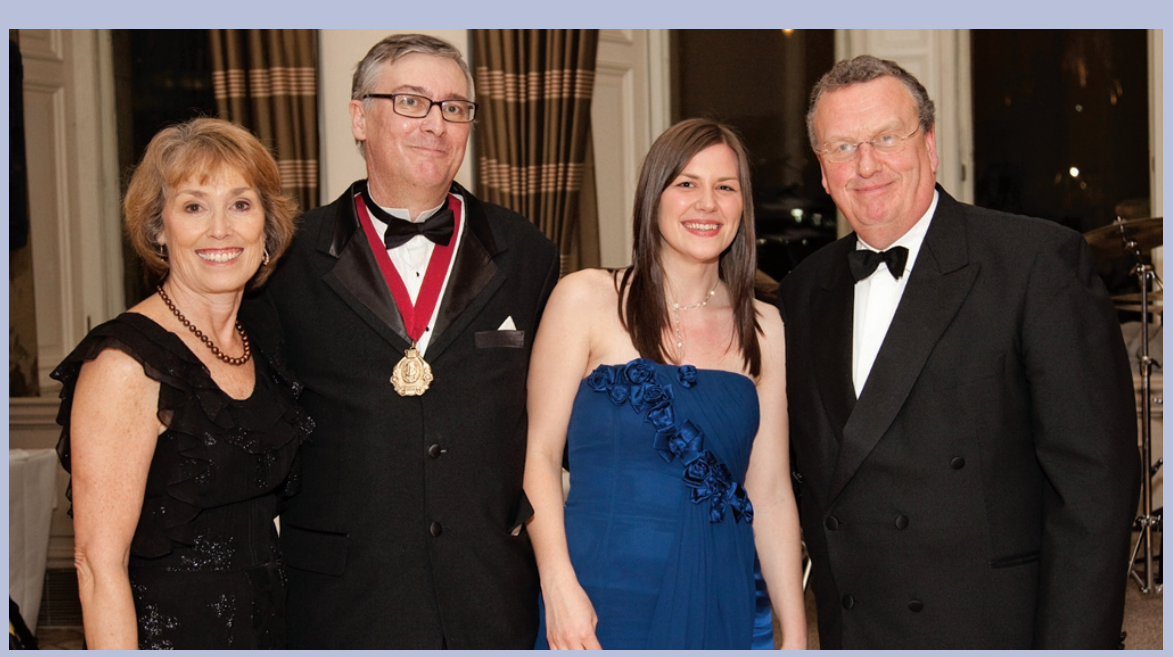

Winner Lisa Durning (second from right), with (from left to right) Linda C. Niessen DMD, Vice President and Chief Clinical Officer DENTSPLY International, Professor John Drummond, President of the British Dental Association, and Professor Nairn Wilson of King's College London Dental Institute
Accepting the award, Lisa said, 'I am fantastic to be involved in research as an undergraduate and I am looking for-

Second place was awarded to Mark Gidley of the University of Sheffield School of Dentistry for his presentation 'Identification and quantification of periodontal pathogens in diabetic patients'. He received a cheque for $£ 500$. A third prize, recognising professionalism and presenting skills, was awarded to Malveen Mann, a student at the University of Birmingham's School of Dentistry.

The awards were judged by Professor Nairn Wilson of King's College London Dental Institute, Professor Robert McConnell of University College Dental School and Hospital Cork, and Dr Susan Hooper of Bristol Dental School. delighted to win this award. It has been ward to presenting again in Orlando.'

\section{MEDICAL DEVICES DIRECTIVE CHANGES}

The General Dental Council (GDC) would like to make registrants aware of a change to the Medical Devices Directive 93/42/EC affecting the provision and manufacture of dental appliances.

The directive has been amended by the European Commission and comes into force on 21 March 2010 in the UK.

The regulations can be found on the Medicines and Healthcare products Regulatory Agency (MHRA) website, including the changes to the Medical Devices Directive 93/42/EC with respect to custom-made devices at www. mhra.gov.uk/Howweregulate/Devices/ RevisionstothemedicaldevicesandAIM DDirectives/index.htm

The GDC will be publishing an updated version of its 'Standards on Commissioning and Manufacturing Dental Appliances' guidance which will include the changes to the Directive. 